\title{
Penerapan Asas Mempersulit Proses Perceraian Pada Persidangan di Pengadilan Agama Bengkulu
}

\author{
Slamet Muljono ${ }^{*}$, Edytiawarman², Dimas Dwi Arso ${ }^{3}$, Nurhani Fithriah ${ }^{4}$ \\ Fakultas Hukum, Universitas Bengkulu \\ *Correspondence email: muljonoslamet@gmail.com, edytia1963@gmail.com,ddarso@unib.ac.id,nurhanifithriah99@gmail.com
}

\begin{abstract}
Marriage is a physical and mental bond between a man and a woman as husband and wife with the aim of forming a happy and eternal family (household) based on the One Godhead. But in reality, there are still many households that end up in divorce. To prevent divorce in the household, positive marriage law in Indonesia adheres to the principle of complicating divorce, the application of which is manifested in the necessity for reasons as regulated in law and divorce can only be made with a decision to file will be implemented at the time of the divorce process in court Religion. This research aims to understand the application of the principle of complicating divorce in the Bengkulu Class 1A Religious Court, with the following problems: What are the factors causing the divorce in the Bengkulu Class 1A Religious Court and, how does the implementation of the principle complicate the divorce process in the divorce trial at the Bengkulu Religious Court. For the purposes of this study, empirical research methods are used, which directly search for data in the field. In analyzing the field data, sociological analysis and normative analysis were used to obtain comprehensive analysis results. Based on the results of field research, it was concluded that divorce in Bengkulu was generally based on economic reasons, and consecutively due to domestic violence, and reasons for having an affair. Of the reasons put forward by the parties who filed for or sue for divorce, most of them are due to economic reasons.
\end{abstract}

Keywords: Divorce; Court Hearing; Principles complicate divorce

\section{PENDAHULUAN}

Perkawinan adalah suatu pranata yang sudah ditetapkan Allah S.W.T agar hubungan suami istri menjadi halal, sehingga seseorang bisa memperoleh keturunan dari perkawinannya, dengan begitu perkawinan merupakan suatu tahap awal bagi laki-laki maupun wanita dalam menciptakan suatu keluarga. Sesungguhnya dengan adanya perkawinan maka tercipta keluarga yang kekal, sakinah, mawadah, rahmah, dan bahagia. Oleh sebab itu, perkawinan harus dipertahankan dan dianggap sebagai suatu perjanjian yang suci.

Hukum Islam menyebutkan bahwa Akad perkawinan tidak hanya perjanjian semata tetapi juga ikatan suci (mitsaqon golidhon) yang berkenaan dengan keimanan kepada Allah S.W.T, sehingga terkandung hal yang bersifat ubudiah dalam suatu perkawinan ${ }^{1}$, Sebab itu, ketika melakukan perkawinan terkandung dimensi vertikal dan dimensi horizontal. Dimensi vertikal yaitu hubungan antara orang pribadi dengan Tuhan yang berkaitan dengan keimanan, dimensi vertikal inilah yang membuat perkawinan sebagai sebuah akad yang suci (mitsaqon golidhon) yang pada hakikatnya mempunyai dimensi ibadah kepada Allah SWT (ubudiyah), sedangkan dimensi horizontal yaitu hubungan antara seorang pria dengan wanita yang saling mengikatkan diri baik itu secara batin maupun secara lahir sebagai suami dan istri untuk menciptakan rumah tangga dan membentuk keluarga, sedangkan Sudarsono memberikan pengertian perkawinan sebagai akad yang memiliki sifat yang suci dan luhur antara laki-laki dan perempuan. ${ }^{2}$

Pasal 1 Undang-undang Nomor Nomor 1 Tahun 1974 sebagaimana telah diubah dengan Undang Undang Nomor 16 Tahun 2019 Tentang Perkawinan disebutkan bahwa : Perkawinan ialah ikatan lahir batin antara seorang pria dengan wanita sebagai suami istri dengan tujuan membentuk keluarga (rumah tangga) yang bahagia dan kekal berdasarkan keTuhanan Yang Maha Esa". Sementara menurut Kompilasi Hukum Islam bahwa "perkawinan bertujuan untuk mewujudkan kehidupan rumah tangga yang sakinah, mawaddah, dan rahmah"3.

Regulasi dalam perkawinan yaitu Kompilasi Hukum Islam (KHI) dan Undang-undang Nomor Nomor 1 Tahun 1974 yang diubah dengan Undang Undang Nomor 16 Tahun 2019 Tentang Perkawinan adalah agar dapat memberikan kepastian hukum dan perlindungannya terhadap hubungan antara seorang laki-laki dan perempuan dalam suatu jalinan sah yang dinamakan suatu ikatan dalam perkawinan. Oleh karena itu, dapat dipahami suatu perkawinan bisa mendatangkan konsekuensi yang dikarenakan akibatnya yang membutuhkan regulasi yang mengatur mengakibatkan persoalan nantinya. Namun kenyatannya, banyak terjadi perkawinan berujung pada perceraian antara suami dan isteri dengan berbagai alasan, termasuk di Kota Bengkulu.

Berdasarkan penelitian awal yang dilakukan oleh penulis, tingkat perceraian di Kota Bengkulu yang melalui proses persidangan di Pengadilan Agama Bengkulu menunjukkan suatu angka yang tergolong tinggi, dan ada

\footnotetext{
${ }^{1}$ Amiur Nurudin dan Azhari Akmal Tarigan, Hukum Perdata Islam di Indonesia (Jakarta: Kencana, 2004$), 206$.

${ }^{2}$ Sudarsono, Hukum Perkawinan Nasional (Jakarta, Rineka Cipta, 2005), 36.

${ }^{3}$ Inpres Nomor 1 Tahun 1991 tentang Kompilasi Hukum Islam Pasal 3.
} 
kecenderungan dari tahun 2018 sampai tahun 2020 menunjukkan angka yang terus meningkat setiap tahunnya. Berdasarkan penelitian awal, perceraian yang terjadi di Kota Bengkulu ini pada tahun 2018 terjadi 907 sidang gugatan perceraian, pada tahun 2019 sampai bulan Oktober 2019, terjadi persidangan proses perceraian sebanyak 1035 kasus, dan untuk tahun 2020, dalam jangka waktu satu bulan, yakni pada bulan Januari telah terjadi persidangan proses perceraian sebanyak 280 kasus. ${ }^{4}$ Tingginya kasus perceraian di Kota Bengkulu seperti tersebut di atas tentu sangat menarik untuk dilakukan kajian. Pada satu sisi sampai sampai Walikota Bengkulu berwacana untuk melarang pelaksanaan perceraian. Walaupun dari aspek sosial hal ini ada benarnya, akan tetapi dari sisi yuridis tentu hal ini tidak bisa dilaksanakan, sebab bisa melanggar Hak Azasi Manusia.

Banyak kajian yang bisa dilakukan untuk bahan studi gejala terjadinya perceraian di Kota Bengkulu ini, salah satunya adalah tentang kajian dari aspek Proses Beracara Dalam Perkara Perceraian, khususnya yang berkaitan dengan penerapan asas "Mempersulit Proses Perceraian". Sebagaimana yang diatur dalam penjelasan umum UU No 1 Tahun 1974 yang diganti dengan UU No16 Tahun 2019 Tentang Perkawinan angka 4 huruf e, selaku berikut: sebab pernikahan bertujuan menghasilkan sesuatu keluarga bahagia, kekal dan sejahtera, maka UU Perkawinan mengatur prinsip untuk mempersukar terciptanya perceraian. Perceraian dapat dimungkinkan, namun berdasarkan alasan yang diakui dalam undang-undang dan harus dilakukan pada sidang pengadilan. Berdasarkan pertimbangan tersebut, maka penting untuk dilakukan penelitian mengenai penerapan asas "Mempersulit Proses Perceraian" dalam Proses persidangan gugatan di Pengadilan Agama Bengkulu.

Penelitian ini mengangkat rumusan masalah sebagai berikut:

1. Faktor apa saja menjadi pemicu terjadinya perceraian di Pengadilan Agama Kelas 1A Bengkulu?

2. Bagaimanakah implementasi asas mempersulit proses perceraian dalam persidangan gugatan perceraian di Pengadilan Agama Klas 1A Bengkulu?

\section{METODE}

Metode pendekatan yuridis sosiologis atau empiris digunakan dalam penelitian ini, karena meneliti data primer berkaitan dengan asas mempersulit proses perceraian dalam gugatan perceraian di Pengadilan Agama Kelas IA Bengkulu. Deskriptif analisis merupakan sifat penelitian ini sehingga dapat menjawab permasalahan secara terstruktur dan utuh mengenai obyek yang dikaji yaitu penerapan asas mempersulit proses perceraian dalam persidangan gugatan perceraian di Pengadilan Agama Bengkulu.

Guna mendapatkan data yang sahih, penulis menerapkan purposive sampling dalam metodenya, yaitu melakukan penelitian kepada responden yang dipilih terlebih dahulu berdasarkan kriteria yang dianggap memiliki kemampuan dan pengetahuan terhadap obyek penelitian. Berdasarkan metode pemilihan responden ini, responden yang diplih adalah : Ketua Pengadilan Agama Kelas 1A Bengkulu, 3 (tiga) orang Hakim pada Pengadilan Agama Kelas 1A Bengkulu dan Panitera Sekretaris pada Pengadilan Agama Kelas 1A Bengkulu. Kemudian dilakukan analisis data kualitatif yaitu data diterima kemudian dibuat terstruktur serta dilakukan analisis guna mendapatkan pemahaman penerapan asas mempersulit proses perceraian dalam gugatan perceraian di Pengadilan Agama Bengkulu.

\section{HASIL DAN PEMBAHASAN}

\section{Tingkat Perceraian Di Pengadilan Agama Kelas 1A Bengkulu}

Pasal 1 Undang-Undang Republik Indonesia Nomor 1 Tahun 1974 Tentang Perkawinan yang telah diubah Undang Undang Republik Indonesia Nomor 16 Tahun 2019 Tentang Perubahan Atas UndangUndang Nomor 1 Tahun 1974 Tentang Perkawinan diatur bahwa, : "Perkawinan ialah ikatan lahir bathin antara seorang pria dengan seorang wanita sebagai suami isteri dengan tujuan membentuk keluarga (rumah tangga) yang bahagia dan kekal berdasarkan Ketuhanan Yang Maha Esa. Selanjutnya menurut perspektif Hukum Islam disebutkan tujuan perkawinan membentuk keluarga sakinah, mawadah wa rohmah, Sakinah bersumber dari bahasa Arab artinya aman, damai, ketentraman, dan ketenangan. Sebagaimana sesuai dengan maknanya, keluarga sakinah artinya keluarga yang didalamnya mengandung keamanan, kedamaian, ketentraman, dan ketenangan. ${ }^{5}$ Mawaddah berusumber dari bahasa Arab yang artinya cinta yang menggebu, membara dan perasaan kasih sayang. Mawaddah digunakan bagi sebutan rasa cinta yang membara pada kekasihnya. Pada fitrahnya, mawaddah ini pasti dimiliki manusia. Timbulnya rasa cinta yang membara ini ada faktor yang sebabnya bisa dilihat berdasarkan segi fisik pasangannya, tingkah laku, jabatan dan faktor yang dimiliki kekasihnya. Rasa cinta dan kasih sayang dimiliki oleh keluarga karena adanya Mawaddah.

Keluarga akan menjadi hambar bila tidak berlandaskan rasa cinta. Rasa cinta dalam keluarga mendatangkan rasa untuk mengikhlaskan suatu hal buat keluarganya. Rasa cinta dapat mendatangkan sifat untuk menjaga serta

${ }^{4}$ Berdasarkan hasil wawancara penulis dengan Panitera Muda Hukum bernama November 2020, pukul 09.52 WIB.

Rita Elviyanti, S.H. pada tanggal 12

${ }^{5}$ https://dalamislam.com/hukum-islam/pernikahan/keluarga-sakinah-mawaddah-wa-rahmah diakses pada tanggal 19 November 2020 Pukul 18.50 WIB 
memiliki. ${ }^{6}$ Kata Rahmah bersumber dari bahasa Arab yang memiliki arti ampunan, karunia, rezeki, dan rahmat. Allah SWT memberikan rahmah terbesar kepada keluarga yang diliputi rasa kepercayaan, kasih, sayang, dan cinta. Keluarga yang memiliki rasa rahmah tidak akan timbul dalam sekejap melainkan timbul karena memberikan pengertian, saling memahami, kekurangan ditutupi, dan sama-sama membutuhkan.. ${ }^{7}$ Akan tetapi tujuan yang mulia dalam perkawinan sebagaimana disebutkan di atas, namun dalam kenyataan sehari-hari masih banyak dijumpai adanya keluarga yang tidak memenuhi harapan tersebut, sehingga perkawinan tersebut berujung pada terjadinya perceraian, seperti halnya yang terjadi di beberapa keluarga di Wilayah Hukum Pengadilan Agama Bengkulu. Hal ini dapat ditunjukkan adanya tingkat perceraian yang terus mengalami peningkatan dari tahun 2018 sampai dengan tahun 2020 ini.

Pada tahun 2018 data dari Pengadilan Agama Kelas IA Bengkulu ada 907 gugatan perceraian. Dari jumlah tersebut, setengahnya (419 perkara) adalah Pegawai Negeri Sipil (PNS) yang mengajukan perceraian. Sementara jumlah perkara tahun 2019 sampai bulan Oktober 2019 mencapai 888 perkaara gugatan perceraian. Pada tahun 2020, Kasus perceraian di Kota Bengkulu pada masa pandemi Covid-19 juga mengalami peningkatan. Dari data yang masuk ke Pengadilan Agama Kela IA Bengkulu, dari bulan Januari sampai bulan Agustus 2020 ada sekitar 900 perkara gugatan dan permohonan cerai. ${ }^{8}$ Menurut Panitera Pengadilan Agama Kelas IA Bengkulu, Agusalim, pada awal masa pandemi Covid-19, pihaknya sempat membatasi pendaftaran gugatan maupun permohonan cerai, karena untuk mengikuti protokol kesehatan. Pada bulan Maret 2020, ada 85 gugatan perceraian, selanjutnya pada bulan April 2020, terdapat 20 gugatan perceraian, dan pada bulan Mei 2020, terdapat 33 gugatan perceraian. Namun, setelah adanya adaptasi kebiasaan baru (AKB), jumlah perkara pun naik. Pada bulan Juni 2020 tercatat ada 97 gugatan, selanjutnya pada bulan Juli 2020 terdapat 143 gugatan. "Namun pada bulan Agusutus 2020 angkanya mengalami penurunan menjadi 91 gugatan. ${ }^{9}$

\section{Faktor Pemicu Terjadinya Perceraian Di Pengadilan Agama Kelas 1A Bengkulu}

Menurut ketentuan Pasal 19 Peraturan Pemerintah Republik Indonesia Nomor 9 Tahun 1975 Tentang Pelaksanaan Undang-Undang Nomor 1 Tahun 1974 Tentang Perkawinan mengatur alasan yang dapat menimbulkan terjadinya perceraian yaitu :

a. Salah satu pihak berbuat zina atau menjadi pemabok, pemadat, penjudi, dan lain sebagainya yang sukar disembuhkan;

b. Salah satu pihak meninggalkan pihak lain selama 2 (dua) tahun berturut-turut tanpa izin pihak lain dan tanpa alasan yang sah atau karena hal lain diluar kemampuannya;

c. Salah satu pihak mendapat hukuman penjara 5 (lima) tahun atau hukuman yang lebih berat setelah perkawinan berlangsung;

d. Salah satu pihak melakukan kekejaman atau penganiayaan berat yang membahayakan pihak yang lain;

e. Salah satu pihak mendapat cacat badan atau penyakit dengan akibat tidak dapat menjalankan kewajibannya sebagai suami/isteri;

f. Antara suami dan isteri terus-menerus terjadi perselisihan dan pertengkaran dan tidak ada harapan akan hidup rukun lagi dalam rumah tangga.

Sedangkan alasan dalam mengajukan perceraian disebut dalam Pasal 116 Kompilasi Hukum Islam yang menentukan bahwa alasan terjadinya perceraian sebagai berikut:

a. Salah satu pihak berbuat zina atau menjadi pemabuk, pemadat, penjudi dan lain sebagainya yang sukar disembuhkan;

b. Salah satu pihak mninggalkan pihak lain selama 2 (dua) tahun berturut-turut tanpa izin pihak lain dan tanpa alasan yang sah atau karena hal lain diluar kemampuannya;

c. Salah satu pihak mendapat hukuman penjara 5 (lima) tahun atau hukuman yang lebih berat setelah perkawinan berlangsung;

d. Salah satu pihak melakukan kekejaman atau penganiayaan berat yang membahayakan pihak lain;

e. Salah satu pihak mendapat cacat badab atau penyakit dengan akibat tidak dapat menjalankan kewajibannya sebagai suami atau isteri;

f. Antara suami dan isteri terus menerus terjadi perselisihan dan pertengkaran dan tidak ada harapan akan hidup rukun lagi dalam rumah tangga;

\footnotetext{
${ }^{6}$ Ibid.

7 Ibid.

${ }^{8}$ Berdasarkan hasil wawancara penulis dengan Panitera Muda Hukum bernama $\quad$ Rita Elviyanti, S.H. pada tanggal 12 November 2020, pukul 09.52 WIB.

${ }^{9}$ Berdasarkan hasil wawancara penulis dengan Panitera bernama Agusalim, S.H., M.H. pada tanggal 12 November 2020 , pukul 10.30 WIB.
} 
g. Suami melanggar taklik talak;

h. Peralihan agama atau murtad yang menyebabkan terjadinya ketidak rukunan dalam rumah tangga.

Hukum Islam juga mengatur putusnya perkawinan dengan alasan sebagai berikut. ${ }^{10}$

a. Talāq. Secara literal talāq berarti lepas dan bebas. Kata talāq dengan perkawinan yang putus karena antara istri dan suami hubungannya sudah lepas. Kitabnya Al-Mahalli menyebutkan "Melepaskan hubungan pernikahan dengan menggunakan lafaz talāq dan sejenisnya". ${ }^{11}$ Sebab, suami dilarang menyebutkan suatu kata yang mudah guna menceraikan istri tanpa kesadaran yang penuh.

b. Khulü.' Khulü' dari bahasa Arab berarti "melepaskan dan menghilangkan", tetapi fuqaha mengartikannya dengan beraneka ragam. Menurut Hanafi kepemilikan nikah yang hilang disebabkan kesepakatan isteri dengan Khulü'.

c. Fasakh. Berdasarkan istilahnya didapatkan kesimpulan, misalnya bersumber pada Kamus Besar Bahasa Indonesia selaku berikut: Pembatalan jalinan pernikahan oleh pengadilan agama berdasarkan tuntutan suami ataupun istri yang bisa dibenarkan oleh Majelis hukum Agama ataupun sebab perkawinan yang telah terlanjur menyalahi hukum perkawinan. ${ }^{12}$

d. Ila'. Ila' yaitu bersumpah bahwa suami tidak akan menggauli istrinya tidak lebih dari 4 bulan atau jangka waktu yang tidak disebutkan. Jika suami bersumpah demi sumpah ini, biarkan dia menunggu hingga 4 bulan. Jika dia kembali ke istrinya 4 bulan yang lalu, dia harus membayar denda untuk sumpah sumpah (Kifarat). Namun, jika dia tidak kembali bersama istrinya hingga 4 bulan, hakim berhak memerintahkan dia untuk memilih di antara dua situasi berikut: menceraikan istrinya atau membayar sumpah Kefarath, dan kemudian kembali kepada istrinya.,. Seandainya dia enggan melakukan salah satu dari kedua perkara tersebut, hakim memiliki hak untuk memaksanya agar terjadi perceraian. ${ }^{13}$

e. Zihār, yaitu seorang laki-laki menyamakan isterinya dengan ibu kandungnya, sehingga isterinya haram untuk digauli, misalnya suami berkata "engkau terlihat olehku seperti ibuku". Bila laki-laki mengucapkan demikian dan tidak dilanjutkan dengan kata talak, ia harus melakukan pembayaran denda kifarat, dan haram hukumnya bila menggauli isterinya sebelum kifarat itu dibayar. ${ }^{14}$

f. Liän. ini adalah sejenis lafaz Arab yang akar katanya adalah laa-'a-na, yang secara harfiah berarti "saling malaknat". Cara ini disebut dalam term liän karena dalam prosesinya kata "laknat" tersebut. Diantara definisi yang digambarkan, yang mudah dipahami adalah: "sumpah suami yang menuduh isterinya berbuat zina, sedangkan dia tidak mampu mendatangkan 4 orang saksi". ${ }^{15}$

g. Nusyüz. Aminuddin dan Slamet Abidin menyebutkan, ${ }^{16}$ nusyüz adalah durhaka, yang berarti kedurhakaan diperbuat isteri kepada suaminya. Bila isteri tidak taat pada suami berdasarkan suatu alasan yang dapat dibenarkan hukum syara', maka itu termasuk tindakan durhaka.

h. Syiqa $\bar{q}$, berarti perselisihan. Perselisihan adalah konflik yang terjadi antara isteri dan suami, pertengkaran, dan pertingkaian. Syiqāq berdasarkan Alquran surat An-Nisa ayat 35: ${ }^{17}$ Yang artinya: "Dan barangsiapa diantara kamu (orang merdeka) yang tidak cukup perbelanjaanny untuk mengawini wanita merdeka lagi beriman, ia boleh mengawin wanita yangberiman, dari budak-budak yang kamu miliki. Allah mengetahui keimananmu; sebahagian kamu adalah dari sebahagian yang lain, karena itu kawinilah mereka dengan seizin tuan mereka, dan berilah maskawin mereka menurut yang patut, sedang merekapun wanita-wanita yang memelihara diri, bukan pezina dan bukan (pula) wanita yang mengambil laki-laki lain sebagai piaraannya; dan apabila mereka telah menjaga diri dengan kawin, kemudian mereka melakukan perbuatan yang keji (zina), maka atas mereka separo hukuman dari hukuman wanita-wanita merdeka yang bersuami (Kebolehan mengawini budak)itu, adalah bagi orang-orang yang takut kepada kemasyakatan menjaga diri (dari perbuatan zina) di antara kamu, dan kesabaran itu lebih baik bagimu. Dan Allah Maha Pengampun lagi Maha Penyayang” (Q.S An-Nisa : 35)

Apabila dicermati, alasan-alasan sebagaimana yang dijadikandasar dalam mengajukan gugat cerai atau permohonan cerai di Pengadilan Agama Kelas 1A Bengkulu, alasan atau alasan-alasan tersebut sebagian ada yang berdasar pada ketentuan sebagaimana diatur pada Pasal 19 PP Nomor 9 Tahun 1975 poin a; d; dan f, yaitu : Salah satu

10 Aripuddin, Penerapan Asas Mempersulit Terjadinya Perceraian (Studi Kasus Di Mahkamah Syar'iyah Kota Banda Aceh) (Banda Aceh: Skripsi, Fakultas Syariah Dan Hukum Universitas Islam Negeri Ar-Raniry Darussalam 2017,) $24-27$.

${ }^{11}$ Amir Syarifuddin, Hukum Perkawinan Islam di Indonesia,(Jakarta, Kencana, 2006), 198.

12 Ibid, hlm. 242.

${ }^{13}$ Beni Ahmad Saebani, Fiqh Munakahat (Buku 1l), (Bandung: Pusaka Setia,2001), 132.

${ }^{14}$ Ibid,. hlm. 133.

${ }^{15}$ Amir Syarifuddin, Op. Cit., hal. 288.

${ }^{16}$ Beni Ahmad Saebani, Op. Cit., hlm. 50.

${ }^{17}$ Ibid. 
pihak berbuat zina; Salah satu pihak melakukan kekejaman atau penganiayaan berat yang membahayakan pihak yang lain; Antara suami dan isteri terus-menerus terjadi perselisihan dan pertengkaran dan tidak ada harapan akan hidup rukun lagi dalam rumah tangga. Sedangkan sebagian besar pengajuan perceraian adalah dengan alasan faktor ekonomi, yang notabene pihak laki-laki (suami) dianggap tidak mampu lagi menafkahi pihak perempuan (isteri).

Pengajuan gugatan perceraian para pihak di Pengadilan Agama Kelas 1A Bengkulu tersebut dilatarbelakangi oleh berbagai sebab dan faktor, namun pengajuan perkara perceraian yang paling mendominasi adalah masalah ekonomi dan petengkaran yang terus menerus-menerus. Sedangkan penyebab perceraian lainnya diantaranya adalah karena zina, mabuk, judi, KDRT, cacat badan, dan meninggalnya salah satu pihak.

\section{Penerapan Asas Mempersulit Proses Perceraian Dalam Persidangan Gugatan Di Pengadilan Agama Kelas 1A Bengkulu}

Peradilan Islam dan Peradilan Perdata merupakan wewenang dari peradilan Agama, jadi harus sesuai dengan syariat Islam dan regulasi yang ada di Indonesia. Maka, Hukum substansi Acara Peradilan Agama yaitu Segala peraturan baik itu yang bersumber dari peraturan perundang-undangan maupun syariat Islam mengatur bagaimana cara orang menghadap ke muka Pengadilan Agama dan juga mengatur bagaimana cara Pengadilan Agama tersebut menyelesaikan perkaranya, untuk mewujudkan hukum materiil Islam yang menjadi kewenangan Peradilan Agama. ${ }^{18}$

Dalam Pasal 2 jo Pasal 49 UU No. 3 Tahun 2006 Tentang Perubahan atas UU No. 7 Tahun 1989 tentang Pengadilan Agama diatur bahwa tugas dan wewenang Peradilan Agama adalah memeriksa, memutus, dan menyelesaikan di tingkat pertama antara orang-orang yang beragama Islam di bidang: Perkawinan, Waris, Wasiat, Hibah, Wakaf, Infaq, Sedekah dan Ekonomi Syariah. Dengan demikian, Pengadilan Agama sebagai aktualisasi implementasi hukum Islam sebagai pelaku kekuasaan kehakiman bagi rakyat pencari keadilan yang memiliki agama Islam.

Berdasarkan uraian di atas, dapat dipahami bahwa Peradilan Agama adalah perwakilan pemerintahan yang kewenangannya dalam menyelesaikan persengketaan perdata orang-orang yang beragama Islam termasuk bidang perkawinan, perceraian. Pengadilan Agama dapat mengupayakan pencegahan agar tidak terjadi perceraian, yang sesuai dengan asas dalam Undang-Undang Perkawinan yaitu tasas mempersukar terjadinya perceraian. Adanya asas atau prinsip mempersulit terjadinya tidak menutup kemungkinan untuk terjadinya perceraian, melainkan hanya mempersulit pelaksanaan perceraian saja, yang berarti perceraian tetap terjadi jika tidak dapat dihindarkan lagi. ${ }^{19}$ Selain asas atau prinsip tersebut, menurut Pasal 58 ayat (2) UU No 7 Tahun 1989 tentang Pengadilan Agama jo Pasal 2 ayat (4) dan Pasal 4 ayat (2) UU No 48 Tahun 2009 tentang Kekuasaan Kehakiman mengatur bahwa, : Pengadilan membantu para pencari keadilan dan berusaha sekeras-kerasnya mengatasi segala hambatan dan rintangan untuk tercapainya peradilan yang sederhana, cepat dan biaya ringan. Pasal 58 ayat (2) UU No 7 Tahun 1989 Pengadilan membantu para pencari keadilan dan berusaha sekeras-kerasnya mengatasi segala hambatan dan rintangan untuk tercapainya peradilan yang sederhana, cepat dan biaya ringan. Pasal 2 ayat (4) dan Pasal 4 ayat (2) UU No 48 Tahun 2009 peradilan dilakukan dengan sederhana, cepat dan biaya ringan. Penerapan asas atau prinsip mempersulit perceraian dalam praktik peradilan, dapat ditafsirkan dari ketentuan peraturan perundangan bahwa :

1. Untuk melakukan perceraian, pihak-pihak yang ingin bercerai harus mengajukan gugatan atau permohonan yang diajukan ke Pengadilan Agama. Berdasarkan gugatan atau permohonan perceraian ini kemudian pengadilan akan menyidangkan dan memberi putusan apakah mengabulkan gugatan atau permohona cerai tersebut ataukan menolak permohonan atau gugatan cerai tersebut. Gugatan cerai diatur dalan Pasal 132

Kompilasi Hukum Islam bahwa gugat cerai diajukan oleh isteri atau kuasanya pada Pengadilan Agama, yang daerah hukumnya mewilayahi tempat tinggal penggugat kecuali isteri meninggalkan tempat kediaman bersama tanpa izin suami (ayat 1). Dalam hal tergugat bertempat kediaman diluar negeri, Ketua Pengadilan Agama memberitahukan gugatan tersebut kepada tergugat melalui perwakilan Republik Indonesia setempat. (ayat 2). Sedangkan untuk gugat cerai diajukan oleh suami kepada isterinya melalui sidang Pengadilan disebutkan pada Pasal 129 Kompilasi Hukum Islam mengatur bahwa, seorang suami yang akan menjatuhkan talak kepada isterinya mengajukan permohonan baik lisan maupun tertulis kepada Pengadilan Agama yang mewilayahi tempat tinggal isteri disertai dengan alasan serta meminta agar diadakan sidang untuk keperluan itu . Pengadilan akan melakukan sidang gugatan atau permohonan perceraian berdasarkan prosudur dan mekanisme yang sudah dtentukan oleh peraturan perundangan tentang prosedur beracara di Pengadilan Agama.

2. Pengajuan gugatan atau permohonan talak harus disertai alasan.

\footnotetext{
${ }^{18}$ Roihan Rasyid, Hukum Acara Hukum Acara Peradilan Agama, (Jakarta: Raja Grafindo Persada, 2015$) 10$.

${ }^{19}$ Nasruddin Amir dan Azhari Akmal, Hukum Perdata Islam Indonesia, (Jakarta: Kencana, 2004), 54.
} 
berikut:

Penerapan asas atau prinsip mempersulit perceraian di Pengadilan Agama Kelas 1A dapat diuraikan sebagai

1. Perceraian hanya bisa diputuskan oleh pengadilan.

Menurut ketentuan Pasal 114 "Kumpulan Hukum Islam" disebutkan bahwa karena perceraian atau berdasarkan proses perceraian, maka dapat terjadi gagalnya perkawinan yang disebabkan oleh perceraian. Perjanjian cerai juga diatur dalam Pasal 117 sd 122 KHI, yaitu perceraian merupakan jaminan yang dibuat oleh suami dalam persidangan pengadilan agama, yang menjadi salah satu alasan pembubaran perkawinan sebagaimana dimaksud dalam Pasal 129, 130 dan 131. Kemudian dijelaskan pula pada Pasal 118 taitu Talak Raj'I adalah talak pertama atau kedua, dimana suami berhak rujujk selamaisteri dalam masa iddah. Selain itu mengenai Talak Ba in Shughraa yaitu talak yang tidak boleh dirujuk tapi boleh akad nikah baru dengan bekas suaminya meskipun dalam iddah. Talak Ba`in Shughraa sebagaimana tersebut pada Pasal 119 Ayat (1) yaitu: talak yang terjadi qabla al dukhul; talak dengan tebusan atahu khuluk; talak dikeluarkan dari Pengadilan Agama.

Talak Ba in Kubraa berdasarkan Pasal 120 KHI adalah talak yang dilakukan untuk ketiga kalinya. Talak Ba'in ini tidak dimungkinkan untuk dirujuk dan tidak dapat dinikahkan kembali, kecuali pernikahan tersebut dilakukan setelah bekas isteri menikah degan orang lain dan kemudian terjadi perceraian ba da al dukhul dan sudah habis masa iddahnya. Selanjutnya dijelaskan mengenai Talak Sunny pada Pasal 121 yaitu talak yang dibolehkan alak yang dijatuhkan terhadap isteri yang sedang suci dan tidak dicampuri dalam waktu suci tersebut. Pasal 122 Talak bid ' I adalah talak yang dilarang, yaitu talak yang dijatuhkan pada waktu isteri dalam keadaan haid atau isteri dalam keadaan suci tapi sudah dicampuri pada waktu suci tersebut. Selanjutnya pada Pasal 115 dijelaskan bahwa: Perceraian hanya dapat dilakukan di depan sidang Pengadilan Agama setelah Pengadilan Agama tersebut telah berusaha dan tidak berhasil mendamaikan kedua belah pihak.

Menurut peraturan Pemerintah Republik Indonesia (Nomor 9 Tahun 1975 tentang Pelaksanaan UndangUndang Perkawinan Nomor 1 Tahun 1974), Pasal 16 mengatur: Pengadilan hanya memutuskan untuk mengadakan sidang pengadilan untuk menyaksikan perceraian tersebut. dalam kesaksian. Jika ada alasan yang diatur dalam Pasal 19 "Peraturan Pemerintah" ini, maka dalam Pasal 14 pengadilan menyatakan bahwa tidak mungkin lagi mendamaikan suami dan istri untuk hidup rukun dalam keluarga. Berdasarkan penafsiran Pasal 16 ditetapkan bahwa setelah persidangan memeriksa dan memperdebatkan alasan perceraian, dan mencoba menengahi kedua belah pihak tanpa hasil, kemudian disaksikan perceraian suami di persidangan. Pasal 14 PP tersebut menyebutkan: Bagi seorang suami yang menikah menurut agama Islam dan bermaksud menceraikan istrinya, dimohonkan surat ke pengadilan di tempat kediamannya yang memuat pemberitahuan niatnya untuk menceraikan istrinya. Istri dan alasannya, dan meminta pengadilan untuk mengadakan sidang untuk ini.

Berdasarkan pengaturan pada pasal-pasal sebagaimana disebutkan di atas dapat diketahui bahwa pada hakekatnya perceraian itu dapat terjadi berdasarkan talak atau gugatan ke pengadilan. Meskipun demikian, baik perceraian itu dilakukan dengan cara talak atau gugatan perceraian, kedua-duanya harus diputuskan melalui puutusan sidang pengadilan yang menetapkan terjadinya perceraian. Gugat cerai tersebut diajukan oleh Seorang suami yang telah menikah menurut agama Islam dan menceraikan istrinya harus mengajukan surat ke pengadilan di tempat tinggalnya, yang berisi pemberitahuan tentang niatnya untuk menceraikan istrinya dan meminta pengadilan agar diadakan siding perceraian. Bagi seorang suami yang akan melakukan talak kepada isterinya diatur dalam Berdasarkan ketentuan Pasal 129 KHI yang menetukan bahwa: Seorang suami yang akan menjatuhkan talak kepada isterinya mengajukan permohonan baik lisan maupun tertulis kepada Pengadilan Agama yang mewilayahi tempat tinggal isteri disertai dengan alasan serta meminta agar diadakan sidang untuk keperluan itu. Bagi seorang isteri yang akan mengajukan gugatan cerai kepada suaminya diatur dalam Pasal 132 Kompilasi Hukum Islam yang menetukan bahwa,: Gugatan perceraian diajukan oleh isteri atau kuasanya pada Pengadilan Agama, yang daerah hukumnya mewilayahi tempat tinggal penggugat kecuali isteri meninggalkan tempat kediaman bersama tanpa izin suami (ayat 1). Dalam hal tergugat bertempat tinggal di luar negeri, Ketua Pengadilan Agama memberitahukan gugatan tersebut kepada tergugat melalui perwakilan Republik Indonesia setempat (ayat 2). Apabila gugatan atau permohonan cerai tersebut masuk ke Pengadilan, sebelum diputuskan, hakim akan aktif mengusahakan perdamaian di antara keduanya. Apabila hakim tidak berhasil mengupayakan perdamaian, sidang akan diteruskan dengan mengadakan pemeriksaan dan pembuktian secata tertutup, sampai diperoleh kesimpulan sebagai dasar bagi hakim untuk mengambil keputusan. Keputusan tentang penetapan telah terjadi perceraian tersebut diputuskan oleh hakim dalam sidang pengadilan setelah pengadilan tersebut berusaha mendamaikan dan gagal mendamaikan kedua belah pihak. Di persidanan setelah meneliti dan berpendapat adanya alasan-alasan untuk perceraian dan setelah berusaha untuk mendamaikan kedua belah pihak dan tidak berhasil, kemudian menyaksikan perceraian yang dilakukan oleh suami itu dalam sidang tersebut. Putusan Pengadilan Agama ini diatur dalam Pasal Pasal 146 Kompilasi Hukum Islam. Pasal 146 ini dapat dimengerti bahwa dalam proses persidangan perceraian, pemeriksaan dan pembuktiannya dilakukan secara tertutup, tetapi putusan harus dinyatakan pada siding yang terbuka. Hal ini untuk memenuhi asas peradilan yang terbuka terbuka untuk umum. 
2. Gugatan atau permohonan cerai harus disertai alasan

Pasal 39 ayat (2) UU No 1 Tahun 1974 yang diubah dengan UU No 16 Tahun 2019 Tentang Perkawinan mengatur bahwa: Untuk dapat bercerai harus ada alasan yang cukup agar suami istri tidak dapat hidup rukun. Sebagai suami dan istri. Ketentuan ini kemudian diperkuat dengan PP No 9Tahun 1975 yang mengimplementasikan UU No 1 Tahun 1974 tentang Perkawinan dan Kompilasi Hukum Islam. Pasal 19 PP Nomor 9 Tahun 1975 tentang pelaksanaan Undang-Undang Nomor 1 Tahun 1974 tentang Perkawinan mengatur bahwa perceraian dapat terjadi karena alasan-alasan yang diatur dalam pasal 19, yaitu:

a. Salah satu pihak berbuat zina atau menjadi pemabok, pemadat, penjudi, dan lain sebagainya yang sukar disembuhkan;

b. Salah satu pihak meninggalkan pihak lain selama 2 (dua) tahun berturut-turut tanpa izin pihak lain dan tanpa alasan yang sah atau karena hal lain diluar kemampuannya;

c. Salah satu pihak mendapat hukuman penjara 5 (lima) tahun atau hukuman yang lebih berat setelah perkawinan berlangsung;

d. Salah satu pihak melakukan kekejaman atau penganiayaan berat yang membahayakan pihak yang lain;

e. Salah satu pihak mendapat cacat badan atau penyakit dengan akibat tidak dapat menjalankan kewajibannya sebagai suami/isteri;

f. Antara suami dan isteri terus-menerus terjadi perselisihan dan pertengkaran dan tidak ada harapan akan hidup rukun lagi dalam rumah tangga.

Sementara itu, pengajuan gugatan cerai yang diatur dalam Kompilasi Hukum Islam Pasal 116 Pernyataan Hukum Islam, yang menyebutkan alasan perceraian adalah sebagai berikut:

a. Salah satu pihak berbuat zina atau menjadi pemabuk, pemadat, penjudi dan lain sebagainya yang sukar disembuhkan;

b. Salah satu pihak mninggalkan pihak lain selama 2 (dua) tahun berturut-turut tanpa izin pihak lain dan tanpa alasan yang sah atau karena hal lain diluar kemampuannya;

c. Salah satu pihak mendapat hukuman penjara 5 (lima) tahun atau hukuman yang lebih berat setelah perkawinan berlangsung;

d. Salah satu pihak melakukan kekejaman atau penganiayaan berat yang membahayakan pihak lain;

e. Salah satu pihak mendapat cacat badab atau penyakit dengan akibat tidak dapat menjalankan kewajibannya sebagai suami atau isteri;

f. Antara suami dan isteri terus menerus terjadi perselisihan dan pertengkaran dan tidak ada harapan akan hidup rukun lagi dalam rumah tangga;

g. Suami melanggar taklik talak;

h. Peralihan agama atau murtad yang menyebabkan terjadinya ketidak rukunan dalam rumah tangga.

Alasan ini dapat menjadi pertimbangan oleh Hakim dalam menyelesaikan gugatan atau permohonan perceraian yang dimajukan oleh para pihak. Akan tetapi sebelum Maajelis Hakim menjatuhkan putusan perkara perceraian, terlebih dahulu harus mengusahakan perdamaian kepada para pihak dan melaksanakan pembuktian yang diajukan oleh para pihak dalam pengadilan.

3. Mengupayakan Mediasi Dan Perdamaian

Sebelum Majelis Hakim melakukan proses persidangan, terlebih dahulu akan dilakukan mediasi dan perdamaian antara para pihak yang akan melakukan perceraian. Mediasi adalah cara rekonsiliasi antara istri dan suami yang ingin bercerai. Mediasi ini dilakukan oleh hakim yang ditunjuk di Pengadilan. Mediasti diatur dalam PERMA No. 1 Tahun 2016. Tidak adanya mediasi di persidangan akan mengakibatkan ketidakabsahan putusan hakim. Berdasarkan pasal 2 dan pasal 3 PERMA No. 1 Tahun 2016. Dalam perkara proses mediasi di pengadilan, ia menyatakan bahwa penyelesaian sengketa di luar pengadilan telah menjadi syarat mutlak, karena dalam hal ia tidak melanjutkan proses persidangannya, ia dianggap telah melanggar proses peradilan tersebut.

Mediasi dilaksanakan jika salah satu pasangan nikah ada yg tidak sepakat untuk melakukan perceraian. Misalnya, jika istri mengajukan gugatan cerai tetapi suami menyatakan enggan cerai pada sidang pertama, maka mediasi dilakukan. Secara etimologis, mediasi berasal dari bahasa latin mediare yang artinya berada di tengah. Kepentingan ini terkait dengan peran pihak ketiga sebagai mediator dalam bertindak sebagai mediator dan dalam menyelesaikan perselisihan antar para pihak. "Berada di tengah" juga berarti bahwa mediator harus tidak memihak dan netral dalam menyelesaikan perselisihan. Ia berkewajiban untuk dapat melindungi kepentingan para pihak yang berselisih secara setara dan adil, sehingga memperkuat kepercayaan para pihak yang bersengketa. ${ }^{20}$ Dalam

${ }^{20}$ Darmawati H, Fungsi Mediasi Dalam Perkara Perceraian, (Jurusan Akidah dan Filsafat Fak. Ushuluddin 
Collins English Dictionary and Thesaurus disebutkan bahwa mediasi adalah kegiatan menjembatani dua pihak yang bersengketa guna menghasilkan kesepakatan (agreement). ${ }^{21}$ Kegiatan ini dilaksanakan oleh mediator seebagai pihak yang ikut membantu dalam mencari berbagai alternatif penyelesaian sengketa. Mediator dalam hal ini adalah mendorong para pihak untuk mencapai kesepakatanyang dapat menyelesaikan persengketaan dan perselisihan.

Mediator tidak dapat memaksakan pihak yang terlibat dalam perkara untuk menerima putusan darinya. Pihak - pihak yang terlibat dalam perkara sajalah yang menentukan kesepakatan yang dikehendaki. Mediator cuma sekedar mengajak mereka secara bersama-sama untuk menyelesaikan sengketa. ${ }^{22}$ Kamus Besar Bahasa Indonesia mengartikan mediasi yaitu sebagai proses pengikutsertaan pihak ketiga dalam penyelesaian suatu perselisihan sebagai penasihat. ${ }^{23}$ Pengertian mediasi dalam Kamus Besar bahasa Indonesia memiliki tiga unsur penting. Pertama mediasi yaitu proses untuk menyeleesaikan sengketa atau perselisihan antara para pihak. Kedua, mengenai penyelesaian sengketa adalah pihak dari luar yang bersengketa. Ketiga, dalam penyelesaian sengketa merupakan sebagai yang terlibat sebagai penasihat tidak memiliki kewenangan untuk mengambil putusan. ${ }^{24}$

Garry Goopaster memberikan pengertian mediasi sebagai proses negosiasi untuk penyelesaian masalah, dimana pihak luar yang adil bekerjasama dengan pihak yang berselisih untuk membantu mencapai kesepakatan yang memuaskan. ${ }^{25}$ Goodpaster mencoba mendeskripsikan lebih jauh arti mediasi dalam bahasa, tetapi juga mendeskripsikan proses kegiatan mediasi, status dan fungsi pihak ketiga, serta manfaat mediasi. Goodpaster menekankan bahwa mediasi adalah proses negosiasi di mana pihak ketiga berkomunikasi dengan para pihak yang bersengketa dan mencoba mencari cara untuk menyelesaikan sengketa tersebut. Adanya pihak ketiga ini membantu pihak yang berselisih mencari solusi, sehingga tercapainya kesepakatan yang tidak merugikan kedua belah pihak. ${ }^{26}$

\section{Melakukan pembuktian}

Hukum materiil maupun hukum formil pasti memiliki ratio legis, yakni alasan yang menjadi dasar suatu hokum Hakim yang menerapkan hukum akan mempelajari apakah ada alasan yang ditetapkan oleh undang-undang dan apakah alasan tersebut ada dalam peristiwa tertentu di mana undang-undang tersebut akan diterapkan. Dalam hal ini terdapat suatu kaidah fikih: "Al-hukmu yaduru ma'a 'illatihi wujudan wa 'adaman," yaitu sebuah hukum berlaku bersamaan dengan ada tidaknya illat hukum pada suatu peristiwa kongkrit. ${ }^{27}$

Mengenai perceraian, Pasal 22 ayat 2 PP No 9 Tahun 1975 Tentang Pelaksanaan UU No 1 Tahun 1974 Tentang Perkawinan dan Pasal 76 ayat (1) UU No 7 Tahun 1989 tentang Pengadilan Agama, pada hakikatnya mengatur apabila terjadi konflik dan tidak ada harapan lagi untuk hidup rukun dalam rumah tangga atau syiqaq, maka dalam memutus perceraian wajib mendengarkan orang-orang yang dekat dengan suami istri atau keterangan saksi yang berasal dari keluarga. Pembuktian berkaitan dengan kasus perceraian dengan alasan wajib disertai alat bukti saksi. ${ }^{28}$

Persoalan yang sering muncul dalam praktik adalah ketika pihak Penggugat/Pemohon tidak mampu menghadirkan saksi-saksi untuk membuktikan perselisihan dan pertengkaran yang terjadi beserta sebab-sebabnya. Hal ini menimbulkan pertanyaan, apakah tidak dimungkinkan adanya alat bukti lain dalam perkara tersebut? Terkait dengan masalah di atas, perlu mengetahui apa "illat hukum" ketentuan dalam Pasal 22 ayat 2 PP No 9 Tahun 1975 Tentang Pelaksanaan UU No 1 Tahun 1974 Tentang Perkawinan maupun dalam Pasal 76 ayat (1) UU No 7 Tahun 1989 tentang Pengadilan Agama. Pengetahuan "illat hukum" ini penting agar hakim tidak menerapkan suatu ketentuan hukum secara membabi buta terhadap peristiwa kongkrit yang dihadapinya. ${ }^{29}$

Untuk mengetahui "illat" hukum ini terletak pada Yurisprudensi Mahkamah Agung RI Nomor: 863 K/Pdt/1990 tanggal 28 Nopember 1991 yang menyatakan bahwa tidaklah dibenarkan dalam perkara perceraian

UINAM, Sulesana :Volume 9 Nomor 2 Tahun 2014)

${ }^{21}$ Lorna Gilmour, Collins English Dictionary and Thesaurus, Third Editioan (Great Brotain: Harper Collins Publisher, 2007), 510,

22 Ibid.

23 Tim Penyusun, Kamus Besar Bahasa Indonesia, (Jakarta::Badan Pengembangan dan Pembinaan Bahasa Kementerian Pendidikan dan Kebudayaan Republik Indonesia, 2016),726.

${ }^{24}$ Marwan dan Jimmy P, Kamus Hukum, Cet. I, ;(Surabaya: Reality Publisher, 2009), 427.

${ }^{25}$ Gary Goopaster, Negosiasi dan Mediasi: Sebuah Pedoman Negosiasi dan Penyelesaian Sengketa Melalui Negosiasi, (Jakarta: Elips Project, 1993), 201

${ }^{26}$ Syahrizal Abbas, Mediasi dalam Perspektif Hukum Syariah, Hukum Adat, dan Hukum Nasional Cet. I, (Jakarta: Kencana, 2009), hlm. 6,

${ }^{27}$ Muhamad Isna Wahyudi, Pembuktian Dalam Perkara Perceraian (Penerapan Pasal 22 ayat 2 PP No. 9 Tahun 1975 jo. Pasal 76 ayat 1 UU No. 7 Tahun 1989), https://badilag.mahkamahagung.go.id/artikel/publikasi/artikel/pembuktian-dalamperkara-perceraian-olehmuhamad- isna-wahyudi-1010 diakses pada tanggal 15 November 2020 Pukul 19.10 WIB.

28 Ibid.

${ }^{29}$ Ibid. 
semata-mata didasarkan pada pengakuan dan atau adanya kesepakatan saja, karena dikhawatirkan timbulnya kebohongan, ex Pasal 208 KUHPerdata. Ketentuan Pasal 22 ayat 2 PP No 9 Tahun 1975 Tentang Pelaksanaan UU No 1 Tahun 1974 Tentang Perkawinan maupun dalam Pasal 76 ayat (1) UU No 7 Tahun 1989 tentang Pengadilan Agama sedikit banyak masih dipengaruhi oleh ketentuan yang ada dalam KUHPerdata. ${ }^{30}$

"Illat hukum Pasal 22 ayat 2 PP No 9 Tahun 1975 Tentang Pelaksanaan UU No 1 Tahun 1974 Tentang Perkawinan maupun dalam Pasal 76 ayat (1) UU No 7 Tahun 1989 tentang Pengadilan Agama adalah untuk mencegah kebohongan dalam perceraian yang didasarkan pada pengakuan atau kesepakatan. Ini sejalan dengan tujuan pembuktian yaitu untuk menunjukkan kebenaran sebuah peristiwa.

Berdasarkan uraian tersebut di atas, dalam menerapan ketentuan hukum acara dengan memperhatikan "illat hukumnya penting bagi hakim agar hukum acara tidak menghambat bagi terwujudnya keadilan dan kemaslahatan bagi pihak berperkara. Dalam perkara perceraian, yang merupakan hukum perorangan, memang harus dihindari adanya unsur kebohongan dalam perceraian. Meski demikian bukan berarti hakim kemudian mengabaikan alat bukti selain saksi dalam memeriksa perkara perceraian. Hal tersebut karena pembuktian merupakan suatu cara untuk membuat hakim yakin mengenai dalil-dalil gugatan/bantahan yang ditampilkan pada persidangan. Yang harus membuktikan adalah pihak-pihak yang berperkara, sedangkan hakim hanya akan menilai tentang kekuatan alat bukti yang ditampilkan para pihak. Pasal 163 HIR/238 RBG mengatur: barangsiapa yang mengaku mempunyai hak atau suatu peristiwa, ia harus membuktikan adanya hak atau peristiwa itu. Dalam pembuktian ini yang harus membuktikan adalah pihak- pihak yang berperkara, yaitu menguatkan dalil-dalil atau menyangkal dalil-dalil dari pihak lawannya, berdasarkan kebenaran suatu peristiwa yang diajukan sebagai bukti. Jadi yang dibuktiakn hanya peristiwanya, sedangkan hukumnya adalah tugas hakim. Berdasarkan Pasal 164 HIR, alat-alat bukti dalam hukum acara perdata ada lima macam, ialah:

a. Surat. Sudikno Mertokusumo, menyatakan bahwa ${ }^{31}$ bukti surat ialah segala sesuatu yang memuat tanda bacaan yang dimaksudkan untuk mencurahkan isi hati atau untuk menyampaikan buah pikiran seseorang dan dipergunakan sebagai pembuktian Dalam hukum acara perdata dikenal macam-macam surat, yaitu ada tiga macam, yaitu: surat biasa, akta autentik, dan akta di bawah tangan.

b. Saksi. Pasal 164 HIR dan Pasal 184 HIR. Yang dimaksud saksi ialah orang-orang yang mengalami, mendengar, merasakan dan melihat sendiri suatu peristiwa atau kejadian dalam perkara yang sedang dipersengketakan.

c. Persangkaan, ialah kesimpulan hakim yang ditarik dari suatu peristiwa yang telah dianggap terbukti atau peristiwa yang dikenal ke arah sutu peristiwa yang belum terbukti, yang menarik kesimpulan itu adalah Hakim dan Undang-Undang. Persangkaan itu sendiri ada dua, yaitu:

1) Praesuntiones juris yaitu persangkaan berdasarkaan undang-undang. Dalam persangkaan ini Hakim terikat pada ketentuan undang-undang, kecuali jika dilumpuhkan oleh bukti lawan ${ }^{32}$

2) Praesuntiones facti yaitu kesimpulan yang ditarik oleh hakim berdasarkan pengetahuannya dalam jalannya persidangan.

d. Pengakuan Dalam hukum acara perdata terdapat dua jenis pengakuan yaitu:

1) Pengakuan di pengadilan

2) Pengakuan di luar pengadilan

Menurut Pasal 174 HIR, perbedaan antara kedua pengakuan tersebut adalah tidak perlu dibuktikan lagi untuk pengakuan pengadilan, sedangkan pengakuan di luar pengadilan masih memerlukan pembuktian lebih lanjut oleh saksi dan alat bukti lainnya

e. Sumpah. Menurut Gatot Supramono, ${ }^{33}$ sumpah adalah keterangan yang diberikan seseorang dengan mengatasnamakan Tuhannya. Sumpah diatur dalam Pasal 155, 156, 157, 158 dan 177 HIR. Dikenal tiga jenis sumpah alat bukti, yaitu:

1) Sumpah suppletoir, yaitu sumpah yang diperintahkan oleh hakim karena jabatannya kepada salah satu pihak untuk melengkapi pembuktian peristiwa, kejadian yang menjadi sengketa. Pembebanan sumpah ini bukan kewajiban akan tetapi sekedar menjadi wewenangnya untuk itu harus diangkat syaratsyaratnya (HIR Pasal 155 dan R.Bg Pasal 182).

2) Sumpah estimatoir/sumpah penaksiran, yaitu Sumpah penaksiran yang diperintahkan oleh Hakim karena jabatannya kepada penggugat untuk menentukan jumlah atau besarnya ganti rugi. Kekuatan pembuktian sumpah ini sama dengan sumpah suppletoir, bersifat sempurna dan masih dimungkinkan adanya bukti lawan.

\footnotetext{
30 Ibid.

${ }^{31}$ Sudikno Mertokusumo, Hukum Acara Perdata Indonesia, (Yogyakarta: Liberty, 1988), 116.

32 Mukti Arto, Praktek Perkara Perdata Pada Pengadilan Agama, cetakan 1, (Yogyakarta: Pustaka Pelajar,1996), 171.

${ }^{33}$ Gatot Supramono, Hukum Pembuktian Di Peradilan Agama, (Bandung: Alumni,1993), 44.
} 
3) Sumpah decisoir/sumpah pemutus, yaitu Sumpah yang dibebankan atas permintaan salah satu pihak kepada pihak lawannya. (HIR Pasal 156 dan R.Bg. Pasal 183).

\section{SIMPULAN}

Adapun kesimpulan dari penelitian ini adalah sebagai berikut:

1. Penyebab tingginya tingkat perceraian di Kota Bengkulu disebabkan oleh faktor faktor sebagaimana dirumuskan pada Pasal 39 Inpres No 1 Tahun 1991 tentang Kompilasi Hukum Islamm maupun Pasal 19 Peraturan Pemerintah Republik Indonesia Nomor 9 Tahun 1975 Tentang Pelaksanaan Undang-Undang Nomor 1 Tahun 1974 Tentang Perkawinan, yang sebagian besar adalah faktor alasan ekonomi, kemudian disusul oleh alasan KDRT, dan salah satu pihak melakukan perselingkuhan

2. Penerapan asas atau sistem mempersulit perceraian di Pengadilan Agama Kelas 1A Bengkulu dilakukan dengan cara-cara sebagai berikut :

a. Perceraian hanya bisa dilakukan dengan putusan Pengadilan.

b. Permohonan atau gugat cerai harus disertaidengan alasan yang bisa dibenarkan oleh regulasi.

c. Dilakukan mediasi yang dipimpin oleh mediator kepada pihak yang bercerai sebelum dilakukan pemeriksaan perkara dan pembuktian alat-alat bukti oleh Hakim yang memimpin sidang perceraian.

d. Sebelum Majelis Hakim memberikan putusan Pengadilan, terlebih dulu akan dilakukan pembuktian terhadap kebenaran-kebenaran alasan yang diajukan para pihak yang melakukan perceraian guna menghindari kebohongan, sebagai yang menjadi perimbangan hakim untuk memutuskan kasus perceraian.

\section{Saran}

1. Untuk menekan angka perceraian di Kota Bengkulu, disarankan untuk meningkatkan koordinasi antara Badanbadan terkait seperti Kantor Departemen Agama, BP4, Tokoh Agama/Ustad, Kyai, dan Pengadilan Agama, untuk melakukan sosialisasi tentang seputar perkawinan, kepada para remaja, agar lebih siap dan memahami tentang lembaga perkawinan.

2. Kepada Pengadilan Agama disarankan untuk lebih meng-efektivkan-kan pelaksanaan mediasi kepada para pihak yang akan melakukan perceraian semaksimal mungkin, dalam mencegah terjadinya perceraian.

\section{DAFTAR PUSTAKA \\ Buku-buku}

Abdul Manan, Penerapan Hukum Acara Perdata di Lingkungan Peradilan Agama, Jakarta: Kencana Perdana Media Group, 2001.

---------, Penerapan Hukum Acara Perdata di Lingkungan Peradilan Agama, Jakarta: Kencana Perdana Media Group, 2001 Abdul Manan, Aneka Masalah Hukum Perdata Islam di Indonesia, Cetakan I, Jakarta, Kencana Perdana Media Group, 2006.

Amir Syarifuddin, Hukum Perkawinan Islam di Indonesia,Jakarta, Kencana, 2006.

Amiur Nurudin dan Azhari Akmal Tarigan, Hukum Perdata Islam di Indonesia, Kencana, Jakarta, 2004.

Aripuddin, Penerapan Asas Mempersulit Terjadinya Perceraian (Studi Kasus Di Mahkamah Syar'iyah Kota Banda Aceh) Skripsi, Fakultas Syariah Dan Hukum Universitas Islam Negeri Ar-Raniry Darussalam-Banda Aceh, 2017.

Beni Ahmad Saebani, Fiqh Munakahat (Buku ll), Bandung: Pusaka Setia, 2001.

Gary Goopaster, Negosiasi dan Mediasi: Sebuah Pedoman Negosiasi dan Penyelesaian Sengketa Melalui Negosiasi, Jakarta: Elips Project,1993.

Gatot Supramon, Hukum Pembuktian Di Peradilan Agama, Bandung: Alumni, 1993.

Marwan dan Jimmy P, Kamus Hukum, (Cet. I; Surabaya: Reality Publisher), 2009.

Mohd Idris Ramulyo, Hukum Perkawinan Islam, Jakarta: PT Bumi Aksara, 2002.

Mukti Arto, Praktek Perkara Perdata Pada Pengadilan Agama, cetakan 1, Yogyakarta: Pustaka Pelajar, 1996.

Rahmad Rosyadi., A, M. Rais Ahmad, Formalisasi Syariat Islam Dalam Perspektif Tata Hukum Islam, Bogor: Galai Indonesia, 2006.

Roihan Rasyid, Hukum Acara Hukum Acara Peradilan Agama, Jakarta: Raja Grafindo Persada, 2015.

Satjipto Rahardjo, Hukum dan Masyarakat. Bandung: Angkasa, 1986.

Soemiyati, Hukum Perkawinan Islam dan Undang-undang Perkawinan, Yogyakarta: Liberty Yogyakarta, 1989.

Soeroso., R, Praktek Hukum Acara Perdata; Tata Cara dan Proses Persidangan, Jakarta; Sinar Grafika, 2001.

Sudarsono, Hukum Kekeluargaan Nasional, Jakarta: PT. Rineka Cipta, 1991.

Sudarsono, Hukum Perkawinan Nasional, Jakarta, Rineka Cipta, 2005.

Sudikno Mertokusumo, Hukum Acara Perdata Indonesia, Yogyakarta: Liberty, 1988.

Sulaikin Lubis, Hukum Acara Peradilan Agama di Indonesia, Jakarta: Kencan, 2006. 
Slamet Muljono, Edytiawarman, Dimas Dwi Arso dan Nurhani Fithriah, Penerapan Asas Mempersulit Proses Perceraian Pada Persidangan di Pengadilan Agama Bengkulu

Syahrizal Abbas, Mediasi dalam Perspektif Hukum Syariah, Hukum Adat, dan Hukum Nasional, Cet. I; Jakarta: Kencana, 2009.

\section{Peraturan Perundang-undangan}

Undang-Undang Nomor 50 Tahun 2009 tentang Peradilan Agama Undang-undang Nomor Nomor 1 Tahun 1974 tentang Perkawinan

Undang Undang Nomor 16 Tahun 2019 tentang Perubahan Undang-undang Nomor Nomor 1 Tahun 1974 Tentang Perkawinan

Peraturan Pemerintah Nomor 09 Tahun 1975 Tentang Pelaksanaan Undang-undang Nomor Nomor 1 Tahun 1974 tentang Perkawinan Inpres Nomor 1 Tahun 1991 tentang Kompilasi Hukum Islam

\section{Jurnal, Internet}

https://dalamislam.com/hukum-islam/pernikahan/keluarga-sakinah-mawaddah-wa-rahmah https://badilag.mahkamahagung.go.id/artikel/publikasi/artikel/pembuktian-dalam-perkaraperceraian-olehmuhamad-isna-wahyudi-1010,

Muhamad Isna Wahyudi, Pembuktian Dalam Perkara Perceraian (Penerapan Pasal 22 ayat 2 PP No. 9 Tahun 1975 jo. Pasal 76 ayat 1 UU No. 7 Tahun 1989

Darmawati H, Fungsi Mediasi Dalam Perkara Perceraian, Jurusan Akidah dan Filsafat Fak. Ushuluddin UINAM, Sulesana :Volume 9 Nomor 2 Tahun 2014 